\title{
Urban Traffic Management under Heavy Rainfalls - A Multi-Criteria Scientometric Study
}

\author{
${ }^{*}$ Corresponding author \\ ${ }^{1}$ University of Aveiro, Department of Civil Engineering, RISCO, Aveiro, PORTUGAL \\ 2 University of Aveiro, Department of Environment and Planning, Aveiro, PORTUGAL \\ E-mail: mehdizadeh@ua.pt,jfs@ua.pt,jmacedo@ua.pt \\ DOI: 10.24193/JSSPSI.2020.6.08
}

Reza MEHDIZADEH ANVIGH ${ }^{* 1}$, J osé FIGUEIREDO SILVA², J oaquim MACEDO ${ }^{1}$

https://doi.org/10.24193/JSSPSI.2020.6.08

\begin{abstract}
A B S T RACT
The efficient management of the urban traffic, especially under heavy rainfalls, is a subject of significant environmental, economic and social impact. Hence, exploring the most efficient ways to deal with such conditions is of high importance in order to prevent crisis after heavy rainfalls. In this study, a total of 4087 published papers on urban traffic management strategies, were retrieved from Web of Science (WoS) database using a set of relevant keywords and further critically analyzed. Articles in this field have started to be published since 1955 and considerably increased in number around the beginning of the 2000s. A scientometric study was performed on the achieved results considering several parameters including contributing authors, published studies and citations received. The position of the traffic management under heavy rainfalls was also identified and critically discussed, considering the existing scientific gaps to be addressed by further studies in this field. According to results, these works demonstrate a sigmoidal trend from 1955 to 2019. Also, China and the United States were identified as the leading countries in terms of the scientific output in this area. Among the journals with more published papers, "Transportation Research Record" has received the largest number of citations for the papers published on management of urban traffic. It was also noted that traffic management under heavy rainfalls is still an understudied subject. A detailed discussion on the scientific development in this field is also provided, including the potential applications of scientometry.
\end{abstract}

\section{INTRODUCTION}

In most urban areas all over the world, "traffic congestion" is considered a growing problem that needs efficient and sustainable management tools (Shrestha and Mcdonald, 2009). In this regard, enormous efforts have been made among the scientific community in order to offer the most efficient and sustainable ways to deal with traffic congestion. Traffic management is especially very important when dealing with critical conditions such as flooding by stormwater resulting in intense traffic congestion. The term 'stormwater' refers to that part of the rainfall that runs off directly from the land surface and may include all types of pollutants collected by this water flow (Jefferies and Doménech, 2015). As stated by the European Environment Agency (2010), flooding by stormwater is among the most common and disastrous natural phenomena in Europe during rainy seasons. However, the stormwater consequences on urban activities have not yet been thoroughly studied and managed in terms of traffic management. The resulting pavement flooding may bring plenty of problems for both road users and road owners namely blockage and traffic_congestion, leading 


\section{Reza MEHDIZADEH ANVIGH, J osé FIGUEIREDO SILVA, J oaquim MACEDO \\ Journal of Settlements and Spatial Planning, Special Issue, no. 6 (2020) 71-85 \\ Multi-Criteria Spatial Decision Support Systems for Sustainable Development}

to issues such as increase in the emission of air pollutants and also noise pollution. It is clear that the risk of fatal accidents during rainy weather is higher than under normal weather circumstances regardless of whether the performance evaluation of road traffic control systems is satisfied or not (Jung et al., 2010).

Traffic management, especially when considering heavy rainfalls, can play an important role in any metropolitan city. The lack of efficient traffic management may cause serious problems such as safety issues caused by probable accidents. In this situation, a multi-criteria scientometric study can considerably help in identifying the current situation of the scientific literature in this field, pointing to the progress made and the opportunities for improvements in urban traffic management issues (Davarazar et al., 2019; Davarazar et al., 2020; Zandi et al., 2019).

A scientometric analysis refers to a study that tends to illustrate the current stage of a specific scientific field and the trends over a certain period of time, based on related literature (Mingers and Leydesdorff, 2015). Such an analysis is highly welcome so as to evaluate the development level of research. scientometric studies have been widely used in many scientific areas such as sustainability (Kamali, 2020; Olawumi and Chan, 2018), wastewater treatment (Davarazar et al., 2020; Zandi et al., 2019), gas and energy storage ((Davarazar et al., 2019), green buildings (Darko et al., 2019), among others, by analyzing the research findings using mathematical formulae and visualization approaches (Ahmad and Thaheem, 2017). In this regard, this study aims to perform a scientometric analysis on the published studies in the scientific literature on the management of urban traffic in general, and the progress made in the management of urban traffic under heavy rainfall conditions, using a multi-criteria approach. The results can be further used by researchers who tend to direct their research on the mentioned scientific area by providing a summary of science and recommendations for future studies. It is worthy to state that, to our best knowledge, there is no "scientometric analysis" on the traffic management issues in general and especially on the traffic management under heavy rainfall conditions. The results of the present study provide recommendations for efficient management of the traffic issues, especially under heavy rainfalls and to direct the future research in this regard.

This manuscript has been structured as follows: first, methodology and criteria adopted to carry out the scientometric analysis are presented, followed by results and discussions regarding the scientometric data of the areas related to traffic management, in general, and the share of traffic management studies under heavy rainfall among all the studies performed on this topic. Suggestions for future studies were also provided.

\section{METHODOLOGY}

In the present study, Thomson ISI Web of Science (WoS) database was selected among the available databases such as Elsevier, Wiley Online Library, Taylor \& Francis, Springer Link, ASCE Library, Emerald, ProQuest, EBSCO, IEEE Explore in order to extract the published studies on urban traffic management, in general, and on the measures adopted to control the urban traffic under heavy rainfalls, in particular.

WoS is the most comprehensive database that has been hosting high-quality reports ensuring a high degree of scientific robustness (Olawumi and Chan, 2018). In this regard, WoS database was used to identify the published studies on the traffic management under rainfall conditions, by searching the literature using a combination of keywords including $(\mathrm{ti}=($ traffic + urban $)$ or $\mathrm{ti}=($ traffic + city $)$ or $\mathrm{ti}=($ traffic + rural) or ti $=\left(\right.$ traffic + citi $\left.\left.^{*}\right)\right)($ ti:title) and a combination of this set with (ts=(rainfall or rain* or drain* or ${ }^{*}$ storm* or runoff or ${ }^{*}$ flood* or precipitation)) (ts: subject). The fuzzy search performed using “*” was to cover all possible combinations for the given terms. All scientific articles retrieved were carefully screened to ensure the accuracy of the research performed.

The CiteSpace software (5.3.R4) was utilized to analyze the data obtained by searching the WoS database. Results were saved in WoS as "Marked List" and then downloaded to be processed using CiteSpace software. Various scientometric criteria were considered for the analysis in this study, including publication type, publication year, contributing countries, keywords, authors, cited authors, cited journals, scientific categories, and cited studies.

The following scientific terms were also used to interpret the scientometric results obtained by the search.

The definitions for each term are as follows:

a). Betweenness Centrality (BC). Betweenness Centrality qualifies the centrality of a node by indicating the extent to which it is located in the shortest line between others (Freeman, 1997). This parameter is represented as $\mathrm{BC}(\mathrm{k})$ when $\mathrm{k}$ refers to the node $\mathrm{k}$ (Eq. 1).

$$
B C(k)=\sum_{i \neq j \neq k} \frac{\Delta_{i j}(k)}{\Delta_{i j}}
$$

where:

- $\Delta \mathrm{ij}$ also refers to the number of shortest links between ending nodes $i$ and $j$;

- $\Delta \mathrm{ij}(\mathrm{k})$ represents the number of shortest links crossing the node $\mathrm{k}$.

In case a node contains a high $\mathrm{BC}$, it can be stated that it is located on a significant fraction of the shortest links, meaning that it contains lots of connections with other nodes (Sunil Kumar, Balakrishnan, and Jathavedan, 2014). 
b). Citation Burst (CB). According to Chen (2014) and Kleinberg (2003), "citation burst" identifies the most active area (including certain references, authors, etc.) in a specific scientific field. If there are $n$ batches of published studies; the tth batch contains $r_{t}$ relevant studies out of a total of $\mathrm{d}_{\mathrm{t}}$, then burst defined as:

$$
C B\left(i, r_{t}, d_{t}\right)=-\ln \left[\left(\begin{array}{l}
n \\
k
\end{array}\right) P_{i}^{r_{t}}\left(1-P_{i}\right)^{d_{t}-r_{t}}\right]
$$

c). Sigma. Sigma integrates the strength of the structural and temporal properties of a node in graphs representing the scientometric data (Chen, 2014). Sigma combines the betweenness centrality and the citation burst in order to measure the scientific novelty of a reference (Eq. 3) (Chen, 2011);

Sigma $=(B C+1)^{C B}$

d). Citation Counts (CC). Citation count indicator measures the number of citations received by a certain publication over a certain period of time. CC can be defined either for the authors, for an individual article, or for a particular journal (Leimu and Koricheva, 2005; Lindner et al., 2010).

e). Citation Frequency (CF). $\mathrm{CF}$ is defined as the total number of citations received by a publication over a certain period of time, divided by the citation period (years) (United States Environmental Protection Agency, 2004).

f). Clustering. "Clustering" is utilized when the group under analysis is divided into some subcategories with certain similarities. The strength of a cluster is rated as "\#x". Here, $\mathrm{x}$ may assume integer values $(0,1,2, \ldots$ etc.), based on the similarity of data. In this regard, when data are very similar, it results in a robust cluster. The strongest cluster is identified as "cluster\#O"; clusters \#1, \#2, ... (Aldenderfer and Blashfield, 2007).

\section{RESULTS AND DISCUSSION}

\subsection{Published studies analysis}

The advanced search in WoS database, using the identified set of keywords, resulted in retrieving a total of 4738 studies published since the 1920 s on the topic of traffic management problems. Figure 1 (a) represents the number of articles published per year and the contribution of various types of studies. As can be observed in Figure 1, the number of studies has increased considerably, especially after 2000. However, their annual number follows a sigmoidal trend indicating that there is a decreasing trend in this increasing number of published studies. It can be due to this fact that the state of the art contributions in this regard is becoming, to some extent, more difficult. Such a trend can also be observed in some other scientific areas namely underground carbon dioxide storage, membrane bioreactors for wastewater treatment, biochar for soil amendment, etc. (Davarazar et al., 2019; Davarazar, et al., 2020; Zandi et al., 2019).
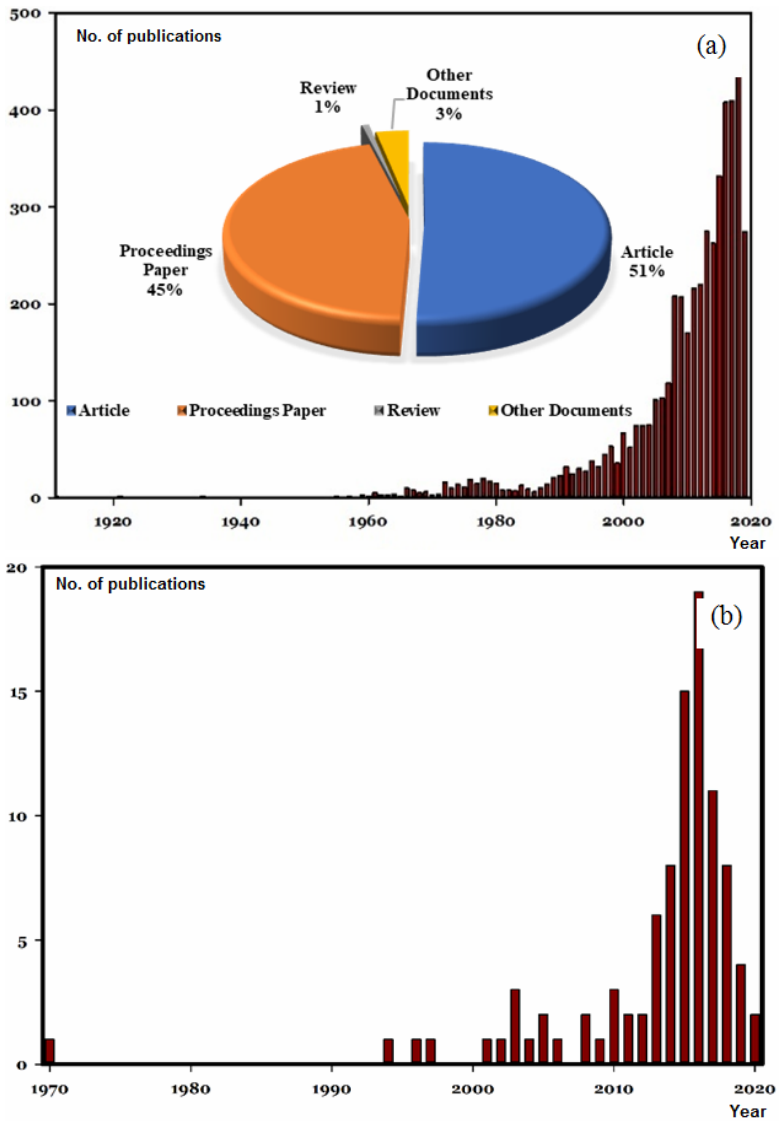

Fig. 1. The number of published studies on urban traffic management and their contribution (a), and the number of studies published on urban traffic management under heavy rainfalls (b).

In addition, Fig. 1 (a) demonstrates that among the studies published in this field, articles have the highest share, corresponding to $51 \%$ of all the published works over the studied period of time, followed by proceedings papers with 45\%, demonstrating the high tendency of the researchers to present their findings in indexed scientific conferences. Despite the importance of the management of traffic under heavy rainfall conditions, the number of academic papers published in the literature on this subject using the mentioned keywords is not considerable, as illustrated in Fig. 1(b). According to data, a total of 96 published studies were selected after refining the set of identified studies based on the applied set of keywords.

\subsection{Keyword analysis}

CiteSpace was employed to analyze the cooccurring of keywords appearing in the studies 
published on urban traffic management aspects. The results are presented in Fig. 2 and Table 1. As can be observed, keywords including "model”, "air pollution”, "system", "flow" and "network" appeared more frequently (313,191, 179, 177, and 137 respectively) among all the keywords that represent the papers published in this scientific area. The font size in Figure 2 represents the relative importance of the nodes.

Figure 3 also demonstrates the trend of the keywords appearance in the literature on urban traffic management. As it is indicated in this figure, air pollution and relevant keywords have been the first set of keywords appeared in the literature. The figure can also demonstrate the current trends in the scientific community, which is now focused on subjects such as deep learning, built environment, and machine learning. However, the keywords of current issues, such as management of urban traffic under heavy rainfall conditions, were not highlighted in the relevant literature. This is probably due to the fact that the number of articles on traffic management under heavy rainfall has not reached a maximum threshold; therefore relevant keywords mentioned in the related scientific studies have not had yet the opportunity to appear among the main keywords used to describe the trends in the traffic management area.

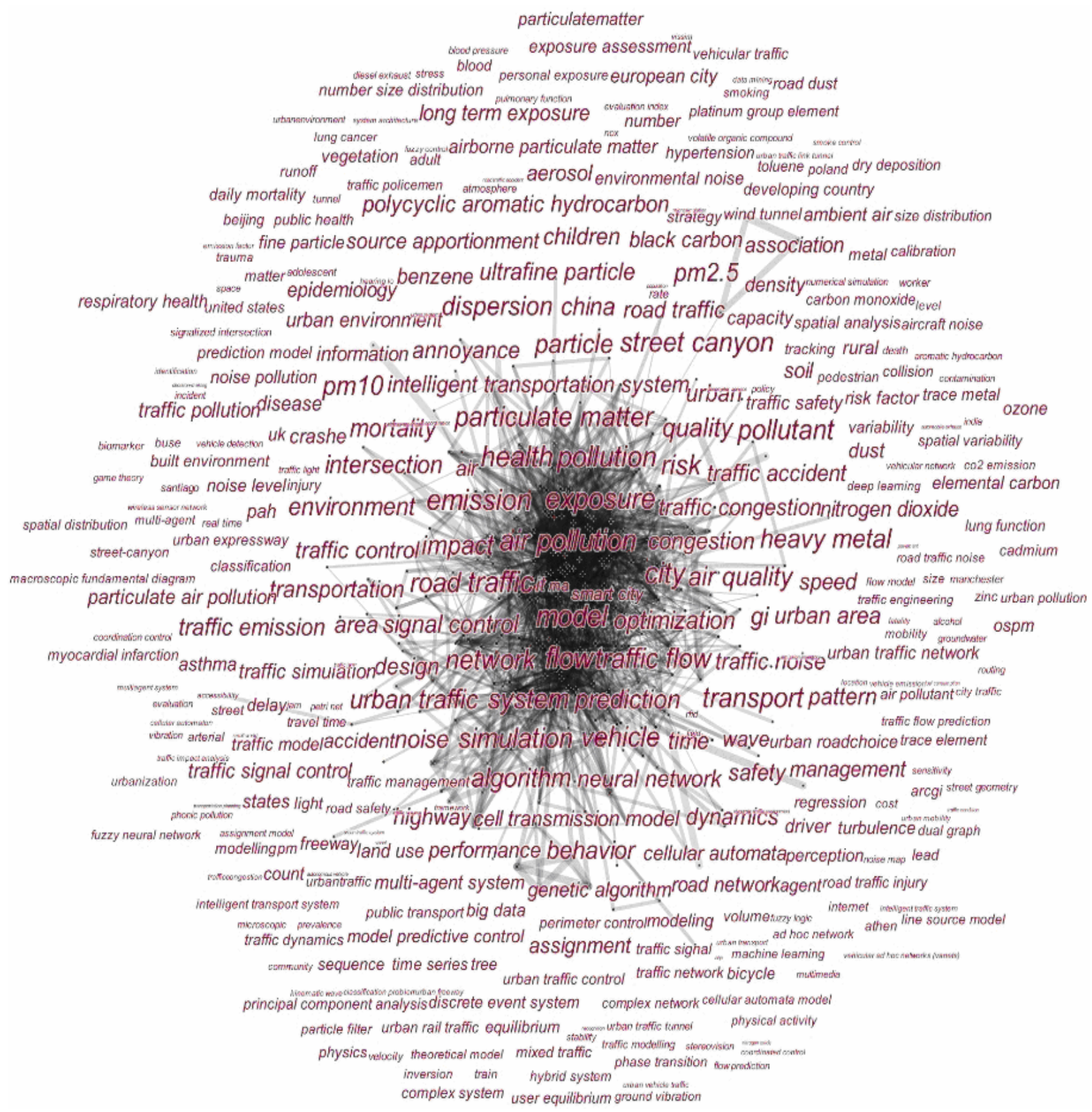

Fig. 2. A schematic representation of co-occurring analysis of the keywords appeared in scientific studies published on urban traffic management. In this figure, the centrality was neglected to represent a clearer illustration. 
Urban Traffic Management under Heavy Rainfalls - A Multi-Criteria Scientometric Study Journal of Settlements and Spatial Planning, Special Issue, no. 6 (2020) 71-85

Multi-Criteria Spatial Decision Support Systems for Sustainable Development

Table 1. The output of keywords co-occurring analysis and respective parameters of scientometric analysis. These keywords are the most widely used to represent the scientific studies published so far on urban traffic management aspects.

\begin{tabular}{|c|c|c|c|c|c|}
\hline Rank & Keyword & Sigma & Centrality & Burst & Frequency \\
\hline 1 & Model & 1.03 & 0.07 & 0.48 & 313 \\
\hline 2 & Air Pollution & 1.49 & 0.08 & 0.5 & 191 \\
\hline 3 & System & 1.28 & 0.08 & 3.37 & 179 \\
\hline 4 & Flow & 1.12 & 0.11 & 1.05 & 177 \\
\hline 5 & Network & 2.16 & 0.07 & 11.83 & 137 \\
\hline 6 & Traffic & 1.38 & 0.06 & 1.87 & 133 \\
\hline 7 & Exposure & 1.23 & 0.05 & 4.57 & 131 \\
\hline 8 & Simulation & 1.05 & 0.07 & 0.74 & 129 \\
\hline 9 & Urban Traffic & 1.08 & 0.05 & 1.64 & 109 \\
\hline 10 & Pollution & 1.21 & 0.07 & 2.63 & 105 \\
\hline 11 & Traffic Flow & 1.15 & 0.08 & 1.93 & 97 \\
\hline 12 & Emission & 1.31 & 0.09 & 3.11 & 89 \\
\hline 13 & Particulate Matter & 1.06 & 0.03 & 1.82 & 87 \\
\hline 14 & Prediction & 1.56 & 0.08 & 5.91 & 87 \\
\hline 15 & Optimization & 1.15 & 0.04 & 3.8 & 84 \\
\hline 16 & Algorithm & 1.14 & 0.03 & 4.08 & 83 \\
\hline 17 & Smart City & 1.05 & 0.00 & 20.52 & 78 \\
\hline 18 & City & 1.07 & 0.08 & 0.87 & 67 \\
\hline 19 & Vehicle & 1.04 & 0.07 & 0.63 & 64 \\
\hline 20 & Traffic Congestion & 1.13 & 0.03 & 4.03 & 61 \\
\hline 21 & Congestion & 1.11 & 0.02 & 4.36 & 61 \\
\hline 22 & Impact & 1.33 & 0.03 & 9.29 & 61 \\
\hline 23 & Health & 1.39 & 0.07 & 4.98 & 58 \\
\hline 24 & Road & 1.18 & 0.06 & 2.63 & 55 \\
\hline 25 & Neural Network & 1.06 & 0.02 & 2.42 & 52 \\
\hline
\end{tabular}

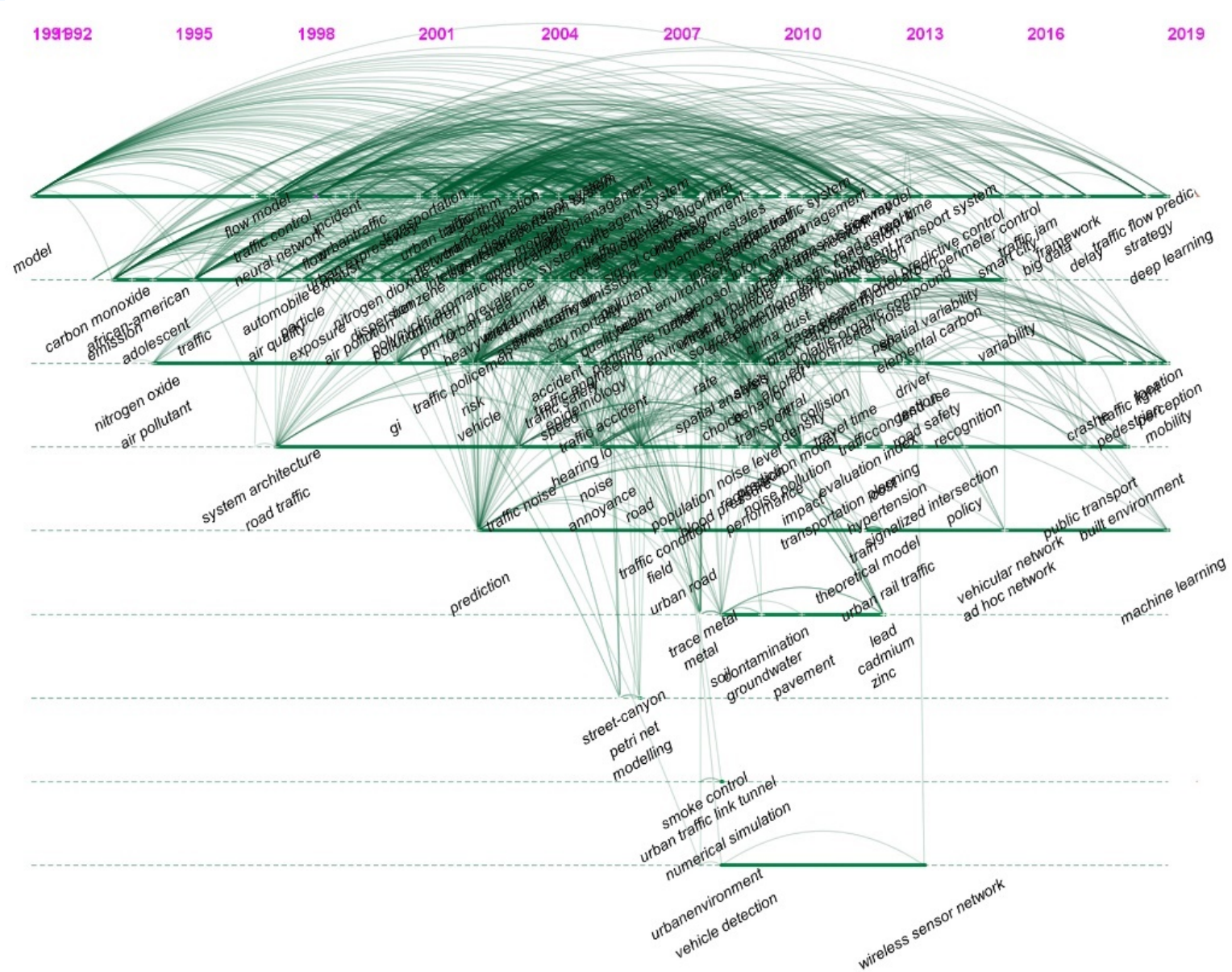

Fig. 3. The appearance of the time-line of keywords applied to represent the scientific studies published on urban traffic management. 


\section{Reza MEHDIZADEH ANVIGH, J osé FIGUEIREDO SILVA, J oaquim MACEDO \\ Journal of Settlements and Spatial Planning, Special Issue, no. 6 (2020) 71-85 \\ Multi-Criteria Spatial Decision Support Systems for Sustainable Development}

\subsection{Contributions}

\subsubsection{Countries}

WoS database was also used to identify the main contributing countries for the publication of scientific articles on urban traffic management. As illustrated in Fig. 4, China (with 1337 studies) is the most important contributing country, followed by the
USA (638) and England (241). The first two mentioned countries were identified as being the most important contributing countries in several scientific fields. China is a particular case that can demonstrate the success of development plans such as "special economic zones of the People's Republic of China", and "economic and technological development zones" (Crane et al., 2018; Zhao et al., 2008).

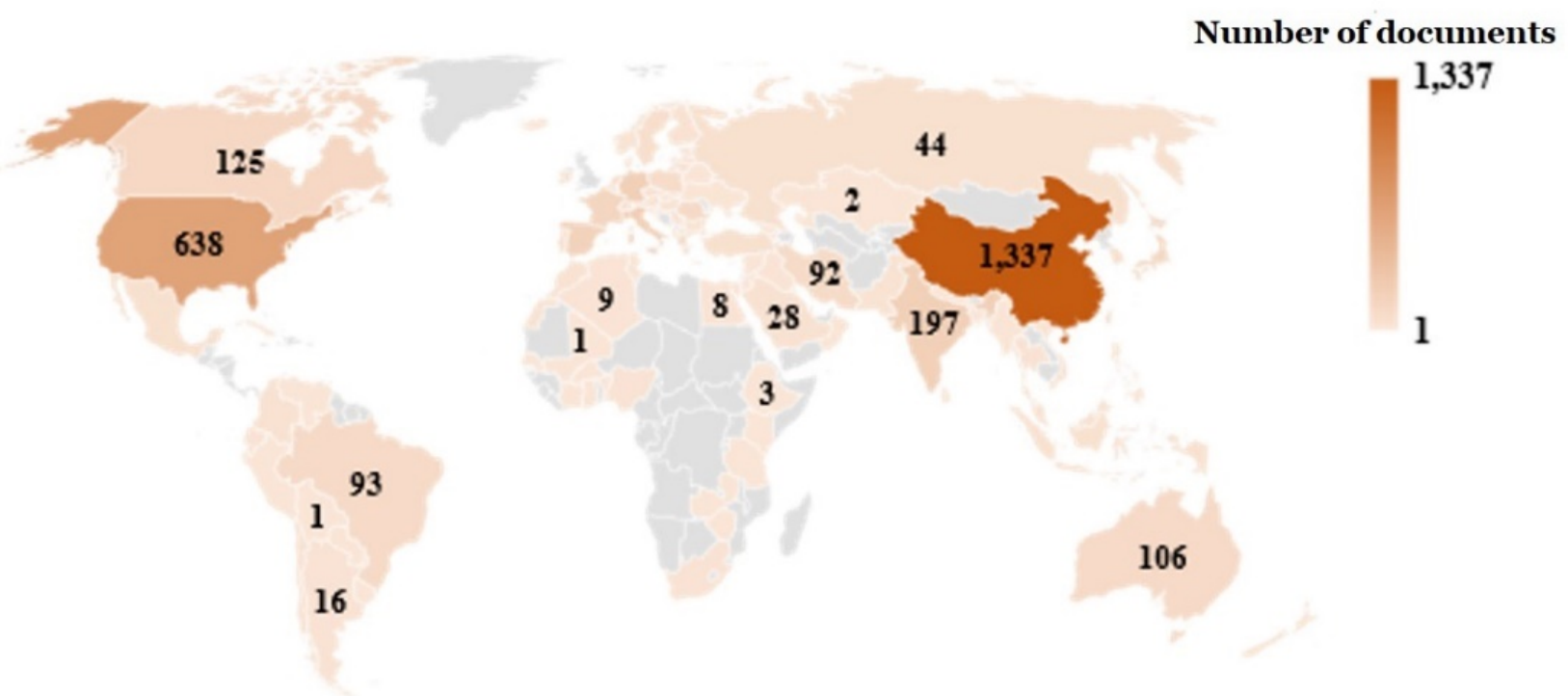

Powered by Bing
D GeoNames, HERE, MSFT, Mcrosaft, Nadnfo, Thinkware Extract, Whipedia

Fig. 4. Contribution of various countries worldwide in the production of studies published on urban traffic management.

\subsubsection{Author analysis}

The contribution of authors of the published studies on urban traffic management is presented in Fig. 5 and Table 2.

Table 2. The list of contributing authors in the publication of scientific articles on urban traffic management, including the detailed information and their respective countries.

\begin{tabular}{cl|rr|} 
Rating & \multicolumn{1}{|c|}{ Author } & $\begin{array}{c}\text { Count } \\
\text { (no.) }\end{array}$ & $\begin{array}{c}\text { Contribution } \\
\text { (\%) }\end{array}$ \\
\hline 1 & Xi YG & 26 & 0.55 \\
2 & Zhang Y & 26 & 0.55 \\
3 & Papageorgiou M & 22 & 0.46 \\
4 & De Schutter B & 21 & 0.44 \\
5 & Li Y & 21 & 0.44 \\
6 & Lin S & 20 & 0.42 \\
7 & Geroliminis N & 19 & 0.40 \\
8 & Anonymous & 18 & 0.38 \\
9 & Jia LM & 18 & 0.38 \\
10 & Liu Y & 18 & 0.38 \\
\hline
\end{tabular}

The nodes in Figure 5 stand for contributing authors, while the links are to represent their cooperation. In addition, the font size of the author's names visualizes the author's extent of contributions.

As can be observed in Fig. 5, "Xi YG", and, "Zhang Y" both with 26 published studies, and "Papageorgiou M" with 22 published studies contributed as the leading authors in the publication of scientific articles on urban traffic issues. In terms of citations received by authors, scientometric parameters including $\mathrm{CC}, \mathrm{CB}$, centrality, sigma, and clustering were considered. Regarding the CC analysis, the first author is Daganzo CF (2002) in Cluster \#3, with a citation count of 221. The second is Papageorgiou M (2002) in Cluster \#3, with a citation count of 168 , and the third is Nagel K (1997) in Cluster \#2, with a citation count of 156 . These are considered as the highlighted authors. With regard to $\mathrm{CB}$ analysis, author Krajzewicz D (2012) in Cluster \#3, with a burst of 15.53 , author Ma XL (2017) in Cluster \#1, with a burst of 14.92, and author Li L (2006) in Cluster \#3, with bursts of 14.31 are identified as the highest-ranked authors. For the centrality, author Krajzewicz D (2012) in Cluster \#3, with the centrality of 0.00, author Ma XL (2017) in 


\section{Urban Traffic Management under Heavy Rainfalls - A Multi-Criteria Scientometric Study Journal of Settlements and Spatial Planning, Special Issue, no. 6 (2020) 71-85 \\ Multi-Criteria Spatial Decision Support Systems for Sustainable Development}

Cluster \#1, with the centrality of 0.00, and author $\mathbf{L i} \mathbf{L}$ (2006) in Cluster \#3, with the centrality of o.oo have received the highest values. Finally, concerning sigma analysis, author Krajzewicz D (2012) in Cluster \#3,

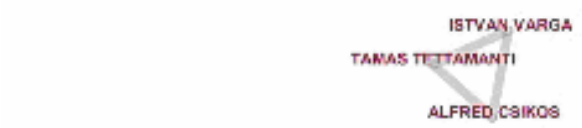

with a sigma of 1.00, author Ma XL (2017) in Cluster \#1, with a sigma of 1.oo, and author Li L (2006) in Cluster \#3, with a sigma of 1.00 registered the highest values among others.

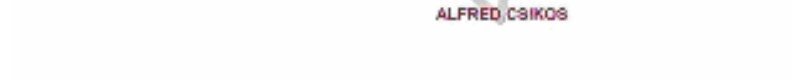

\section{UWANG}

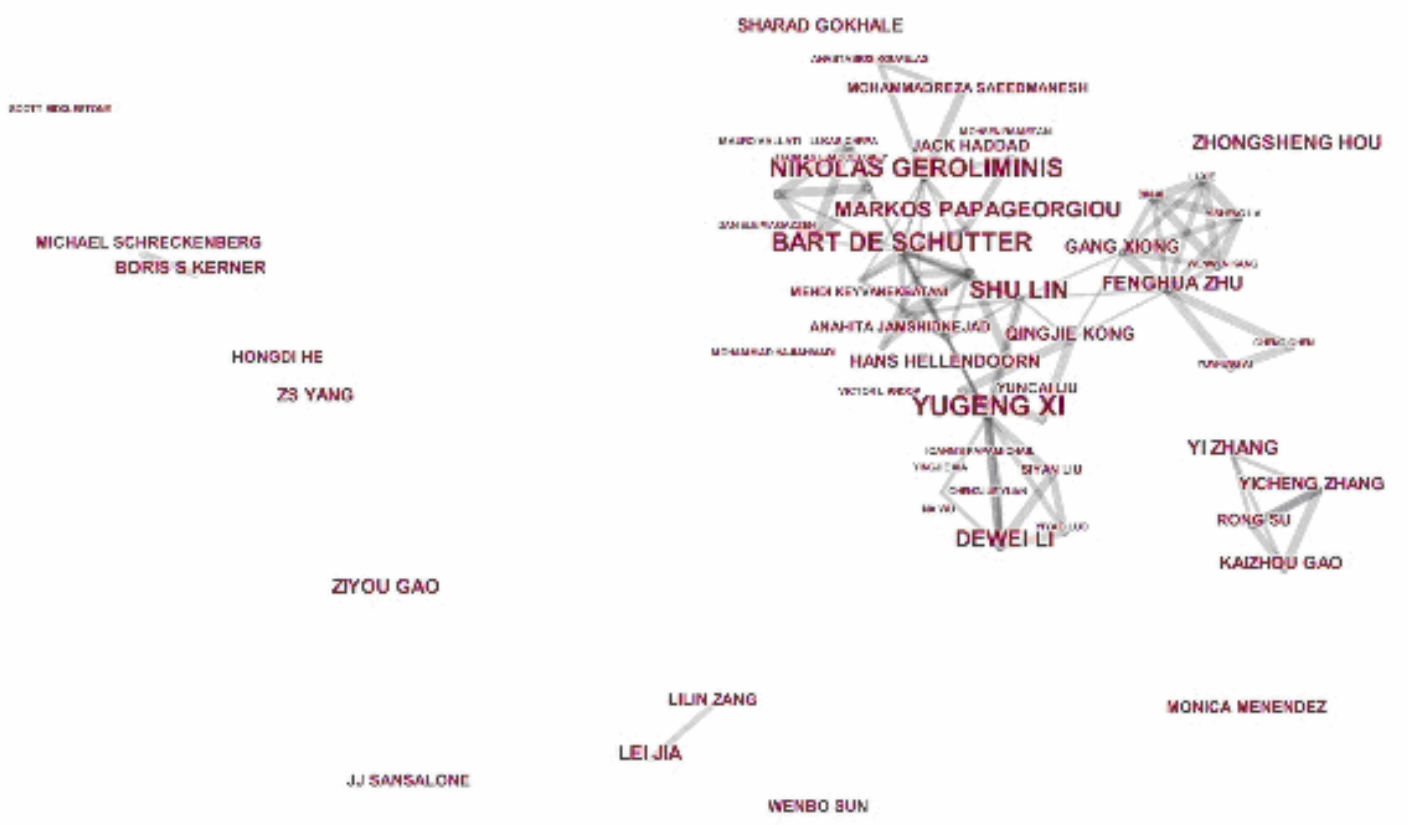

Fig. 5. A schematic to illustrate the contributing authors in the scientific literature on the traffic management issues. This figure is produced with minimum overlaps. This analysis was performed considering all the authorship team members.

Table 3. List of the most cited authors on urban traffic management and respective parameters of scientometric analysis. The parameter "year" in this table indicates the specific year in which the citation burst was initiated.

\begin{tabular}{|c|c|c|c|c|c|}
\hline Rating & Author & Sigma & Centrality & Burst & Frequency \\
\hline 1 & Daganzo CF & 1 & 0 & 0.86 & 221 \\
\hline 2 & Papageorgiou M & 1 & 0 & 1.51 & 168 \\
\hline 3 & Nagel K & 1 & 0 & 3.28 & 156 \\
\hline 4 & Helbing D & 1 & 0 & 0.78 & 131 \\
\hline 5 & Geroliminis $\mathrm{N}$ & 1 & 0 & 12.72 & 119 \\
\hline 6 & Kerner BS & 1 & 0 & 3.84 & 112 \\
\hline 7 & Gartner NH & 1 & 0 & 0.52 & 106 \\
\hline 8 & Aboudolas K & 1 & 0 & 9.66 & 97 \\
\hline 9 & Robertson DI & 1 & 0 & 0.89 & 93 \\
\hline 10 & Lin $S$ & 1 & 0 & 13.48 & 92 \\
\hline 11 & Smith BL & 1 & 0 & 2.61 & 82 \\
\hline 12 & WHO & 1 & 0 & 1.57 & 80 \\
\hline 13 & Diakaki C & 1 & 0 & 4.68 & 79 \\
\hline 14 & Vlahogianni EI & 1 & 0 & 9.93 & 78 \\
\hline 15 & Lighthill MJ & 1 & 0 & 4.49 & 68 \\
\hline 16 & Wang Y & 1 & 0 & 11.92 & 65 \\
\hline 17 & Krajzewicz D & 1 & 0 & 15.53 & 63 \\
\hline 18 & Yang $\mathrm{H}$ & 1 & 0 & 1.7 & 62 \\
\hline 19 & Webster FV & 1 & 0 & 1.29 & 61 \\
\hline 20 & Treiber M & 1 & 0 & 7.28 & 59 \\
\hline
\end{tabular}

Figure 6 and Table 3 show the corresponding data as an output of CiteSpace. In Figure 6, the size of the font represents the importance of each node. For instance, author Daganzo CF (2002), who registered the highest CC, was indicated in Figure 6 at a larger size compared to other authors. Also, this image illustrates 
all of the authors who have published scientific studies

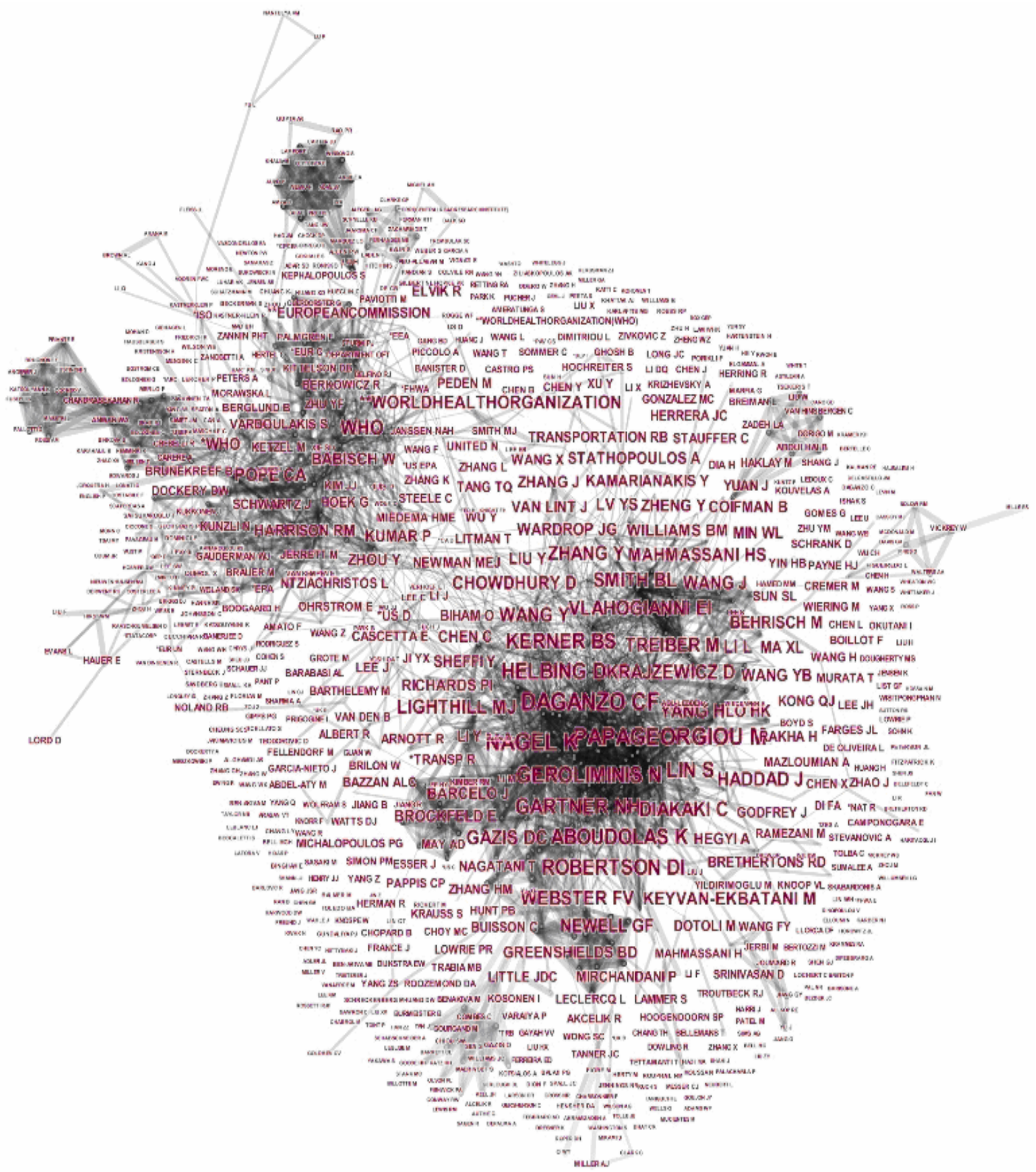

together. In this case, authors are connected by lines.

Fig. 6. A schematic illustration demonstrating the most cited authors publishing scientific studies on urban traffic management. The graph is with minimized overlaps.

\subsubsection{Journal analysis}

Citations received by journals for the publication of scientific studies on urban traffic management issues were used for the scientometric analysis. In this regard, the top-ranked item, by citation counts are: Transport Research Record (Transport RESREC) (1995) in Cluster \#O, with a citation count of 804; Transport Research (Transport RESC) (1998) in Cluster \#O, with a citation count of 770; IEEE Transactions on Information Theory (IEEE TIT) (2005) in Cluster \#O, with a citation count of 636 . In terms of $\mathrm{CB}$, the following can be highlighted: Transport RESREC (1995) in Cluster \#O, with a centrality of 0.15: Atmos $\mathbf{E}$ (1993) in Cluster \#1, with a centrality of 0.14 ; NATURE (2000) in Cluster \#2, with a centrality of o.13. Considering the sigma of the journals, the topranked are: NATURE (2000) in Cluster \#2, with a 
sigma of 3.39; Atmos E (1993) in Cluster \#1, with a sigma of 2.54; THESIS (1998) in Cluster \#O, with a sigma of 2.53 .
Figure 7 and Table 4 reveal the results achieved using CiteSpace. In Figure 7 , the size of the nodes illustrates the importance of the item (journals).

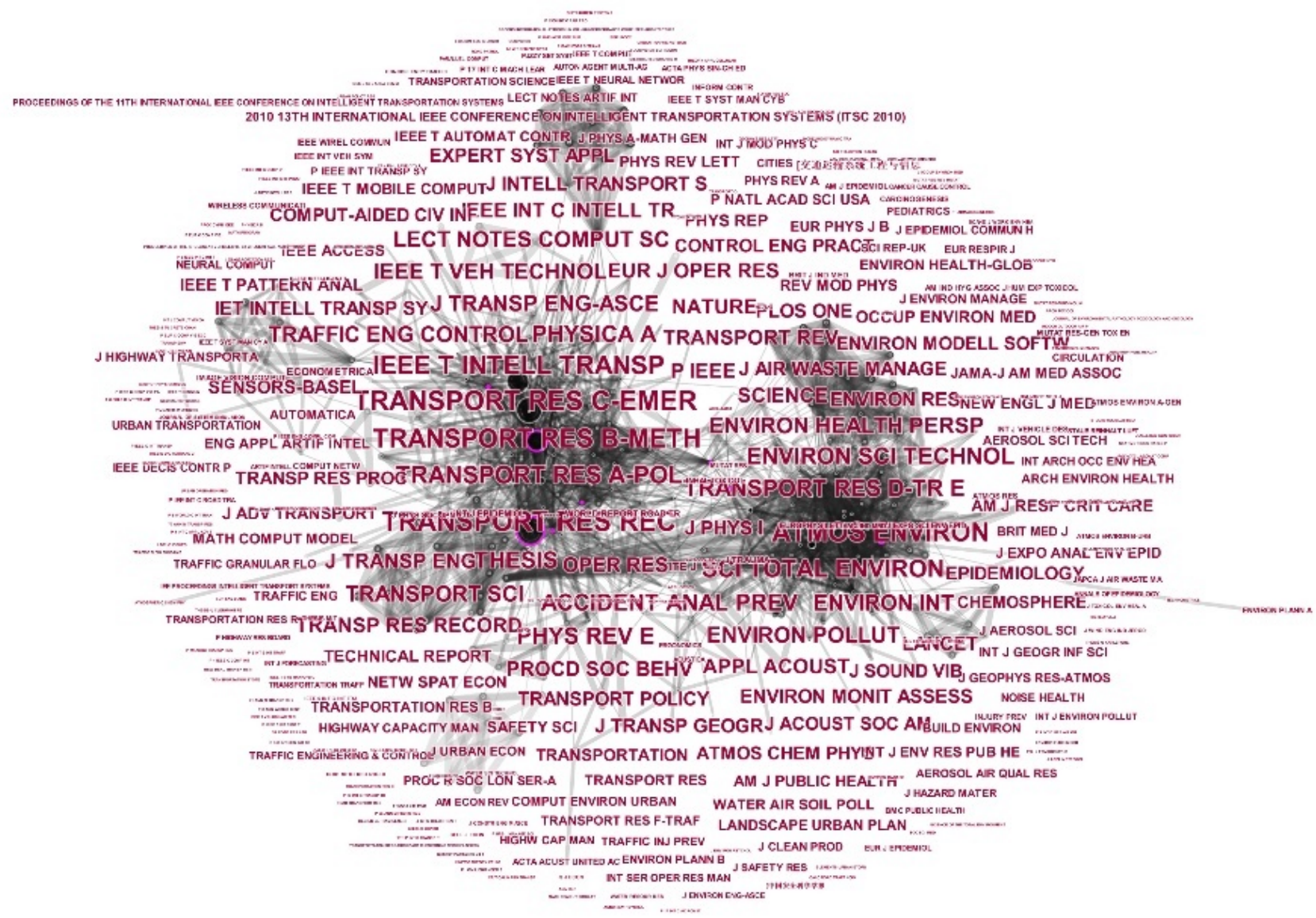

Fig. 7. The cited journals analysis with minimum overlap obtained from CiteSpace. The analysis is based on the number of citations these journals received by publishing the studies on urban traffic management, gathered and analyzed.

Table 4. The detailed information about the journals that recorded citations by publishing the studies collected for the present scientometric study on urban traffic management.

\begin{tabular}{|c|c|c|c|c|c|}
\hline Rating & Journal & Sigma & Centrality & Burst & Frequency \\
\hline 1 & Transportation Research Record & 1.09 & 0.15 & 0.62 & 804 \\
\hline 2 & Transportation Research Part C: Emerging Technologies & 1 & 0.09 & & 770 \\
\hline 3 & IEEE Transactions on Intelligent Transportation Systems & 1.08 & 0.09 & 0.87 & 636 \\
\hline 4 & Transportation Research Part B Methodological & 1.24 & 0.13 & 1.79 & 630 \\
\hline 5 & Atmospheric Environment & 2.54 & 0.14 & 2.25 & 518 \\
\hline 6 & Science of the Total Environment & 1.12 & 0.06 & 1.93 & 448 \\
\hline 7 & Transportation Research Part A: Policy and Practice & 1.08 & 0.08 & 1 & 428 \\
\hline 8 & THESIS & 2.53 & 0.03 & 33.6 & 307 \\
\hline 9 & Transportation Research Part D: Transport and Environment & 1.13 & 0.05 & 2.52 & 285 \\
\hline 10 & Accident Analysis \& Prevention & 1.04 & 0.08 & 0.52 & 277 \\
\hline 11 & Physical Review E & 1.85 & 0.1 & 1.99 & 263 \\
\hline 12 & Environmental Science \& Technology & 1.01 & 0.02 & 0.8 & 258 \\
\hline 13 & PHYSICA A & 1.16 & 0.05 & 2.9 & 245 \\
\hline 14 & Journal of Transportation Engineering & 1 & 0.05 & & 239 \\
\hline 15 & IEEE Transactions on Vehicular Technology & 1.56 & 0.11 & 4.3 & 235 \\
\hline 16 & Environmental Health Perspectives & 1.12 & 0.07 & 1.68 & 229 \\
\hline 17 & Traffic Engineering and Control & 1.93 & 0.07 & 0.78 & 227 \\
\hline 18 & Transportation Science & 1.02 & 0.03 & 0.61 & 205 \\
\hline 19 & Lecture Notes in Computer Science & 1 & 0.05 & & 202 \\
\hline 20 & Environment International & 1 & 0 & 0.72 & 187 \\
\hline
\end{tabular}




\subsubsection{Categories}

"Categories" were defined to classify scientific studies published on the topic of urban traffic management using WoS database. The most important studies) (Fig. 8).

categories were identified as "Engineering" (1839 published studies), “Transportation” (1329 published studies) and "Computer Science" (1113 published

INTERDISCIPLINARY

GREEN \& SUSTAINABLE SCIENCE \& TECHNOLOGY

CONSTRUCTION \& BUILDING TECHNOLOGY COMPUTER SCIENCE, SOFTWARE ENGINEERING

MATERIALS SCIENCE, MULTIDISCIPLINARYIRBAN STUDIES WATER RESOURCES PHYSICS, MATHEMATICALENGINEERING, MULTIDISCIPLINARÝ́KECHANICS nusic

PHYSICS, MULTIDISCIPLINARY ENGINEERING, ENVIRONMENTAL MANAGEMENT COMPUTER SCIENCE, INTERDISCIPLINARY APPLICATIONS MATIC PUB, ENVIRONMENTAL \& OCCUPATIONAL HEALTH

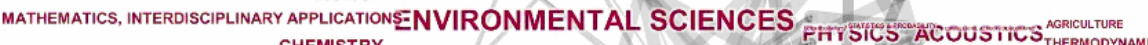

ENVIRONMENTAL SCIENCES \& ECOLOGY STIONISCIENCE \& TECHN

MATERIALS SCIENCETRANSPORTAIILNOPERATIONS RESEARCH \& MANAGEMENT SCIENCE TELECOMMUNICATTIONSENGINEERRING METEOROLOGY \& ATMOSPHERIC SCIENCES

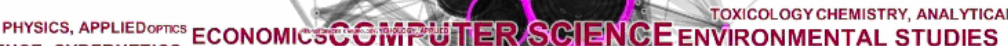
COMPUTER SCIENCE, CYBERNETICS

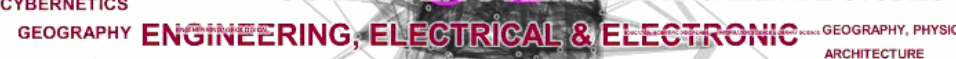

ENGINEERING, MECHANICAL ENGINEERING, CIVIL MATHEMATICS, APPLIED COMPUTER SOIENCE, ARTIFICIAL INTELLIGENCE ENERGY \& FUELS ENGINEERING, INDUSTRIAL AUTOMATION \& CONTROL SYSTEMSROBOTICS GENERAL \& INTERNAL MEDICINE PUBLIC ADMINISTRATIONCOMPUTER SCIENCE, THEORY \& METHODS RESPMATCar GYST PSYCHOLOGYCOMPUTER SCIENCE, INFORMATION SYSTEMS

INSTRUMENTS \& INSTRUMENTATION BUSINESS \& ECONOMICS BUSINESS MEDICINE, GENERAL \& INTERNAL SCIENCE \& TECHNOLOGY - OTHER TOPICSERGONOMICS ${ }^{\text {GEoLoOr }}$ COMPUTER SCIENCE, HARDWARE \& ARCHITECTURE . REMOTE SENSING EDUCATION \& EDUCATIONAL RESEARE IMAGING SCIENCE \& PHOTOGRAPHIC TECHNOLOGY

Fig. 8. Contribution of categories in the production of scientific articles on urban traffic management.

Table 5. Information regarding the categories of published studies obtained from WoS.

\begin{tabular}{|c|c|c|c|}
\hline Rank & Categories & Burst & Frequency \\
\hline 1 & Engineering & & 1839 \\
\hline 2 & Transportation & 24.45 & 1329 \\
\hline 3 & Computer Science & 3.2 & 1113 \\
\hline 4 & Transportation Science \& Technology & 5.17 & 1050 \\
\hline 5 & Electrical \& Electronic Engineering & 0.49 & 823 \\
\hline 6 & Environmental Sciences \& Ecology & 2.65 & 732 \\
\hline 7 & Environmental Sciences & 0.64 & 603 \\
\hline 8 & Civil Engineering & 1.74 & 547 \\
\hline 9 & Artificial Intelligence Computer Science & 4.44 & 507 \\
\hline 10 & Automation \& Control Systems & 2.73 & 337 \\
\hline 11 & Theory \& Methods Computer Science & 2.5 & 323 \\
\hline 12 & Information Systems Computer Science & 8.23 & 308 \\
\hline 13 & Environmental \& Occupational Health Public & 6.24 & 275 \\
\hline 14 & Telecommunications & 0.7 & 261 \\
\hline 15 & Interdisciplinary Applications Computer Science & 10.31 & 254 \\
\hline 16 & Business \& Economics & 1.96 & 181 \\
\hline 17 & Operations Research \& Management Science & 0.75 & 166 \\
\hline 18 & Environmental Engineering & 3.83 & 165 \\
\hline 19 & Environmental Studies & 2.51 & 151 \\
\hline 20 & Mechanical Engineering & 2.77 & 145 \\
\hline
\end{tabular}


Urban Traffic Management under Heavy Rainfalls - A Multi-Criteria Scientometric Study

Journal of Settlements and Spatial Planning, Special Issue, no. 6 (2020) 71-85

Multi-Criteria Spatial Decision Support Systems for Sustainable Development

\subsubsection{Cited published studies}

The most cited published studies on urban traffic management are listed in Table 6. Although several studies have been published on urban traffic management, the topic of management of urban traffic after heavy rainfall has not yet been investigated deeply. Tables 7 and 8 reveal the most contributing countries and the most essential keywords highlighted in the literature on the management of urban traffic under heavy rainfall conditions.

Table 6. The list of the most cited studies in this field obtained from WoS.

\begin{tabular}{|c|c|c|c|c|c|}
\hline Rating & L & Year & Journal & $\begin{array}{l}\text { Citation } \\
\text { (No.) }\end{array}$ & Ref. \\
\hline 1 & $\begin{array}{l}\text { A regression-based method for } \\
\text { mapping traffic-related air } \\
\text { pollution: application and } \\
\text { testing in four contrasting urban } \\
\text { environments }\end{array}$ & 2000 & Science of the total environment & 270 & (Briggs et al., 2000 ) \\
\hline 2 & $\begin{array}{l}\text { An analytical approximation for } \\
\text { the macroscopic fundamental } \\
\text { diagram of urban traffic }\end{array}$ & 2008 & $\begin{array}{l}\text { Transportation research part b- } \\
\text { methodological }\end{array}$ & 257 & $\begin{array}{l}\text { (Daganzo and } \\
\text { Geroliminis, 2008) }\end{array}$ \\
\hline 3 & $\begin{array}{l}\text { A multivariate state space } \\
\text { approach for urban traffic flow } \\
\text { modeling and prediction }\end{array}$ & 2003 & $\begin{array}{l}\text { Transportation research part c- } \\
\text { emerging technologies }\end{array}$ & 257 & $\begin{array}{l}\text { (Stathopoulos and } \\
\text { Karlaftis, 2003) }\end{array}$ \\
\hline 4 & $\begin{array}{l}\text { Optimizing traffic lights in a } \\
\text { cellular automaton model for } \\
\text { city traffic }\end{array}$ & 2001 & Physical review e & 253 & (Brockfeld et al., 2001) \\
\hline 5 & $\begin{array}{l}\text { Urban traffic flow prediction } \\
\text { using a fuzzy-neural approach }\end{array}$ & 2002 & $\begin{array}{l}\text { Transportation research part c- } \\
\text { emerging technologies }\end{array}$ & 234 & (Yin et al.,2002) \\
\hline 6 & $\begin{array}{l}\text { A Review of Computer Vision } \\
\text { Techniques for the Analysis of } \\
\text { Urban Traffic }\end{array}$ & 2011 & $\begin{array}{l}\text { Ieee transactions on intelligent } \\
\text { transportation systems }\end{array}$ & 233 & (Buch et al.,2011) \\
\hline 7 & $\begin{array}{l}\text { Traffic contribution of } \\
\text { polycyclic aromatic } \\
\text { hydrocarbons in the center of a } \\
\text { large city }\end{array}$ & 1996 & Atmospheric environment & 230 & (Nielsen, 1996) \\
\hline 8 & $\begin{array}{l}\text { Robust techniques for } \\
\text { background subtraction in urban } \\
\text { traffic video }\end{array}$ & 2004 & $\begin{array}{l}\text { Visual communications and image } \\
\text { processing } 2004 \text {, pts } 1 \text { and } 2 \text { book } \\
\text { series: proceedings of the society } \\
\text { of photo-optical instrumentation } \\
\text { engineers (spie) }\end{array}$ & 225 & $\begin{array}{l}\text { (Cheung and Kamath, } \\
\text { 2004) }\end{array}$ \\
\hline 9 & $\begin{array}{l}\text { VANET Routing on City Roads } \\
\text { Using Real-Time Vehicular } \\
\text { Traffic Information }\end{array}$ & 2009 & $\begin{array}{l}\text { Ieee transactions on vehicular } \\
\text { technology }\end{array}$ & 219 & (Nzouonta et al.,2009) \\
\hline 10 & $\begin{array}{l}\text { Urban traffic and pollutant } \\
\text { exposure related to respiratory } \\
\text { outcomes and atrophy in a large } \\
\text { sample of children }\end{array}$ & 2003 & European respiratory journal & 205 & (Brogger et al., 2004) \\
\hline
\end{tabular}

Table 7. Contributing countries in the studies on urban traffic management under heavy rainfall conditions.

\begin{tabular}{|c|c|c|c|c|c|c|c|}
\hline Rating & Country & $\begin{array}{l}\text { Count } \\
\text { (No.) }\end{array}$ & $\begin{array}{c}\text { Contribution } \\
(\%)\end{array}$ & Rating & Country & $\begin{array}{l}\text { Count } \\
\text { (No.) }\end{array}$ & $\begin{array}{c}\text { Contribution } \\
(\%)\end{array}$ \\
\hline 1 & China & 34 & 35.42 & 11 & Brazil & 2 & 2.08 \\
\hline 2 & USA & 18 & 18.75 & 12 & India & 2 & 2.08 \\
\hline 3 & Canada & 8 & 8.33 & 13 & Iran & 2 & 2.08 \\
\hline 4 & England & 7 & 7.29 & 14 & Japan & 2 & 2.08 \\
\hline 5 & Australia & 6 & 6.25 & 15 & Norway & 2 & 2.08 \\
\hline 6 & France & 5 & 5.21 & 16 & Pakistan & 2 & 2.08 \\
\hline 7 & Germany & 4 & 4.17 & 17 & Saudi Arabia & 2 & 2.08 \\
\hline 8 & Greece & 4 & 4.17 & 18 & Singapore & 2 & 2.08 \\
\hline 9 & South Korea & 4 & 4.17 & 19 & Austria & 1 & 1.04 \\
\hline 10 & New Zealand & 3 & 3.13 & 20 & Belgium & 1 & 1.04 \\
\hline
\end{tabular}




\section{Reza MEHDIZADEH ANVIGH, J osé FIGUEIREDO SILVA, J oaquim MACEDO \\ Journal of Settlements and Spatial Planning, Special Issue, no. 6 (2020) 71-85 \\ Multi-Criteria Spatial Decision Support Systems for Sustainable Development}

Table 8. The output of keywords co-occurring analysis and respective parameters of scientometric analysis. These keywords are the most widely used to represent scientific studies published so far on urban traffic management under heavy rainfall conditions.

\begin{tabular}{ll|rrrr}
\multicolumn{1}{c|}{ Rank } & \multicolumn{1}{c}{ Keyword } & Sigma & Burst & Frequency \\
\hline 1 & Model & 1.02 & 0.02 & 1.28 & 11 \\
2 & Weather & 1 & 0 & 1.94 & 8 \\
3 & Accident & 1 & 0 & 1.47 & 6 \\
4 & Air Pollution & 1 & 0.01 & 0 & 6 \\
5 & Impact & 1 & 0 & 1.28 & 4 \\
6 & Volume & 1 & 0 & 1.4 & 4 \\
7 & Runoff & 1 & 0 & 1.8 & 3 \\
8 & Risk & 1 & 0 & 1.52 & 3 \\
9 & Heavy Metal & 1 & 0 & 1.8 & 3 \\
10 & Design & 1 & 0 & 1.2 & 2 \\
11 & Neural Network & 1 & 0 & 1.35 & 1.2 \\
12 & System & 1 & 0 & 1 & 2 \\
13 & Montreal & 1 & 0 & 1 & 2 \\
14 & Road & 1 & 0 & 1.1 & 2 \\
15 & Freeway & 1 & 0 & 1.1 & 2 \\
16 & Prediction & 1 & 0 & 1.1 & 2 \\
17 & Network & 1 & 0 & 1 & 2 \\
18 & Mortality & 1 & 0 & 1.35 & 2 \\
19 & Vehicle & 1 & 0 & 1.1 & 2 \\
20 & Safety & 1 & 0 &
\end{tabular}

Table 9. A summary of the main findings and remarks of the papers published in the literature on urban traffic and management under heavy rainfalls.

\begin{tabular}{|c|c|c|}
\hline Title & Main relevant remarks & Ref. \\
\hline $\begin{array}{l}\text { Is city traffic damaged by torrential } \\
\text { rain? }\end{array}$ & $\begin{array}{l}\text { Two quantitative indicators of traffic percolation were used in the city } \\
\text { traffic and according to the results: a) The traffic percolation threshold } \\
\text { is stable against weather perturbation, and b) Some roads are seriously } \\
\text { affected and forming local clusters under torrential rain. }\end{array}$ & $\begin{array}{l}\text { (Guo et al., } \\
\text { 2018) }\end{array}$ \\
\hline $\begin{array}{l}\text { Assessing the Impact of Rainfall on } \\
\text { Traffic Operation of Urban Road } \\
\text { Network }\end{array}$ & $\begin{array}{l}\text { Rainfall had significant negative effects on traffic operation of the } \\
\text { network. Rainy conditions produced maximum production, critical } \\
\text { accumulation and weighted speed-at-capacity, weighted jam density } \\
\text { and weighted free-flow speed reduction of } 9.9 \%, 4.9 \%, 4 \%, 9.6 \% \text { and } \\
1.5 \% \text {, respectively. }\end{array}$ & (Xu et al., 2013) \\
\hline $\begin{array}{l}\text { Impacts of high-intensity storms on } \\
\text { urban transportation: applying } \\
\text { traffic flow control methodologies for } \\
\text { quantifying the effects }\end{array}$ & $\begin{array}{l}\text { The analyses revealed that the prevailing weather conditions, the } \\
\text { intensity of rainfall and the resultant flooding on February the 22nd } \\
\text { had a significant impact on the performance of the Athens } \\
\text { transportation network. }\end{array}$ & $\begin{array}{l}\text { (Mitsakis et } \\
\text { al.,2014) }\end{array}$ \\
\hline $\begin{array}{l}\text { Traffic accident severity analysis } \\
\text { with rain-related factors using } \\
\text { structural equation modeling - A } \\
\text { case study of Seoul City }\end{array}$ & $\begin{array}{l}\text { The results show that the level of accident severity is mutually } \\
\text { correlated with the road factor; traffic, environment, and human } \\
\text { factor; and rain and water depth factor on the road, in this sequence. }\end{array}$ & (Lee et al., 2018) \\
\hline $\begin{array}{l}\text { Evidence of traffic-related pollutant } \\
\text { control in soil-based Sustainable } \\
\text { Urban Drainage Systems (SUDS) }\end{array}$ & $\begin{array}{l}\text { Passing through a swale or detention basin prior to entering a pond is } \\
\text { required for the highway runoff. }\end{array}$ & $\begin{array}{l}\text { (Napier et al., } \\
\text { 2009) }\end{array}$ \\
\hline $\begin{array}{l}\text { Incorporating real-time traffic and } \\
\text { weather data to explore road } \\
\text { accident likelihood and severity in } \\
\text { urban arterials Athanasios }\end{array}$ & $\begin{array}{l}\text { The study added to the current knowledge by incorporating real-time } \\
\text { traffic and weather data from urban arterials to investigate accident } \\
\text { occurrence and accident severity mechanisms. }\end{array}$ & $\begin{array}{l}\text { (Theofilatos, } \\
\text { 2017) }\end{array}$ \\
\hline $\begin{array}{l}\text { Traffic indicators, accidents and } \\
\text { rain: some relationships calibrated } \\
\text { on a French urban motorway } \\
\text { network }\end{array}$ & $\begin{array}{l}\text { Significant relationship between the rain and accident and injury was } \\
\text { discovered by extraction of the data from a one year traffic database } \\
\text { covering } 150 \text { kilometers of two or three lanes urban motorways near } \\
\text { the city of Marseille, in the south of France. }\end{array}$ & $\begin{array}{l}\text { (Aron et al., } \\
\text { 2015) }\end{array}$ \\
\hline
\end{tabular}

During heavy rainfalls, drivers prefer to keep a low speed and drive more cautiously to reduce the risk of accidents (Hussain, 2018). When the capacity of street decreases as a result of heavy rain, it may lead to a long queue. Furthermore, the insufficiency of the existing drainage system may cause the water to be 
accumulated in the depression areas and flood the pavement. This situation will increase travel time and may decrease street capacity. The inundation of roads sometimes lasts for several hours and may be prolonged to a few days if ponding water is not drained using some appropriate facilities for enhancing the drainage capacity, etc. (Youn et al., 2012).

The adoption of the most suitable way to deal with the emergencies created under heavy rainfalls is a complicated task that needs various parameters to be considered in order to reach sustainable management of the urban traffic under such conditions.

Therefore, the main concern is to identify and prioritize some measures to prevent flooding in heavy rain conditions, which would help design an effective urban management system and decrease the possible negative impact. Multi-criteria decision-making models (MCDM) are efficient methods for the identification and prioritization of such factors involved in a complicated context (Hsu, Lee, and Kreng, 2010; Jahanshahi, Kamali, Khalaj, and Khodaparast, 2019; M. Kamali et al., 2017; Kamali et al., 2015). However, there is no report in the literature on the application of these methods to deal with emergency conditions caused by heavy rainfalls. Table 9 presents a summary of the main findings and remarks of the papers published in the literature on urban traffic and management under heavy rainfalls.

\section{CONCLUSION}

The present study is an effort to employ scientometric analysis of the published studies on the management of urban traffic in general and under heavy rainfall conditions, in particular. The study has analyzed a total of 4738 published studies, mainly articles in scientific journals (51\%) to identify the crucial bibliographic information in this regard. China and the United States were identified to be the leading countries with the highest number of published studies. The results of this study indicated that the number of studies published on urban traffic management under heavy rainfall is yet small, and the related keywords do not cover the relevant scientific area of urban traffic management.

The results of the present study may not only be used in the academia, but also by the decisionmakers interested in exploring the appropriate technologies for efficient urban traffic management especially under extreme conditions caused by heavy rainfalls.

\section{REFERENCES}

Ahmad T., Thaheem M. J. (2017), Developing a residential building-related social sustainability assessment framework and its implications for BIM.
Sustainable Cities and Society, 28, 1-15. DOI: https://doi.org/10.1016/j.scs.2016.08.002

Aron M., Billot R., Faouzi N. E. L., Seidowsky R. (2015), Traffic indicators, accidents and rain: some relationships calibrated on a French urban motorway network. Transportation Research Procedia, 10(July), 31-40. DOI: https://doi.org/10.1016/j.trpro.2015.09.053

Baena-Cagnani C. E., Patiño C. M., Cuello M. N., Minervini M. C., Fernández A. M., Garip E. A., Salvucci K. D., Sancho M. L, Gómez R. M. (1999), Prevalence and severity of asthma and wheezing in an adolescent population. International Archives of Allergy and Immunology, 118(2-4), 245-246. https://doi.org/ 10.1159/000024087

Briggs D. J ., Hoogh C. De, Gulliver J., Wills J ., Elliott P., Kingham S., Smallbone K. (2000), A regression-based method for mapping traffic-related air pollution: application and testing in four contrasting urban environments. The Science of the Total Environmen, 151, 151-167.

Brockfeld E., Barlovic R., Schadschneider A., Schreckenberg M. (2001), Optimizing traffic lights in a cellular automaton model for city traffic. Physical Review E - Statistical Physics, Plasmas, Fluids, and Related Interdisciplinary Topics, 64(5), 12. DOI: https://doi.org/10.1103/PhysRevE.64.056132

Brogger J., Eagan T., Eide G. E., Bakke P., Gulsvik A. (2004), Bias in retrospective studies on trends in asthma incidence. European Respiratory Journal, 23(2), 281-286. DOI: https://doi.org/10.1183/ 09031936.03 .00041103

Buch N., Velastin S. A., Orwell J • (2011), A review of computer vision techniques for the analysis of urban traffic. IEEE Transactions on Intelligent Transportation Systems, 12(3), 920-939. DOI: https://doi.org/ 10.1109/TITS.2011.2119372

Chen C. (2014), The citeSpace manual version 1.01. In College of Computing and Informatics (pp. 1-84).

Chen C., Ibekwe-sanjuan F., Hou J. (2011), The structure and dynamics of co-citation clusters: a multiple perspective co-citation analysis. Journal of the American Society for Information Science and Technology, 61(7), 1386-1409. DOI: https://doi.org/ 10.1002/asi.21309

Cheung S. S., Kamath C. (2004), Robust techniques for background subtraction in urban traffic video. Visual Communications and Image Processing 2004, 5308, 881. DOI: https://doi.org/10.1117/12.526886

Aldenderfer M. S., Blashfield R. K. (2007), Cluster Analysis. DOI: https://doi.org/10.4135/9781412983648 Crane B., Albrecht C., Duffin K. M., Albrecht C. (2018), China's special economic zones: An analysis of policy to reduce regional disparities. Regional Studies, Regional Science, 5, 98-107. DOI: https://doi.org/ 10.1080/21681376.2018.1430612

Daganzo C. F., Geroliminis N. (2008), An analytical approximation for the macroscopic 


\section{Reza MEHDIZADEH ANVIGH, J osé FIGUEIREDO SILVA, J oaquim MACEDO \\ Journal of Settlements and Spatial Planning, Special Issue, no. 6 (2020) 71-85 \\ Multi-Criteria Spatial Decision Support Systems for Sustainable Development}

fundamental diagram of urban traffic. Transportation Research Part B: Methodological, 42(9), 771-781. DOI: https://doi.org/10.1016/j.trb.2008.06.008

Darko A., Chan A. P. C., Huo X., Owusu-Manu D. G. (2019), A scientometric analysis and visualization of global green building research. Building and Environment, 149(December 2018), 501-511. DOI: https://doi.org/10.1016/j.buildenv.2018.12.059

Davarazar M., J ahanianfard D., Sheikhnejad Y., Nemati B., Mostafaie A., Zandi S., Khalaj M., Kamali M., Aminabhavi T. M. (2019), Underground carbon dioxide sequestration for climate change mitigation - A scientometric study. Journal of $\mathrm{CO} 2$ Utilization, 33(May), 179-188. DOI: https://doi.org/ 10.1016/j.jcou.2019.05.022

Davarazar M., Mostafaie A., Jahanianfard D., Davarazar P., Aminabhavi T. M. (2020), Treatment technologies for pharmaceutical effluents-A scientometric study. Journal of Environmental Management, 254, 10980o. DOI: https://doi.org/ 10.1016/j.jenvman.2019.109800

Davarazar M., Mostafaie A., Jahanianfard D., Davarazar P., Ghiasi S. A. B., Gorchich M., Nemati M., Kamali M., Aminabhavi T. M. (2020), Treatment technologies for pharmaceutical effluents-A scientometric study. Journal of Environmental Management, 254 (January), 10980o. DOI: https://doi.org/10.1016/j.jenvman.2019.10980o

European Environment Agency (2010), Mapping the impacts of natural hazards and technological accidents in Europe An overview of the last decade. https://doi.org/10.2800/62638

Freeman L. C. (1977), A Set of Measures of Centrality Based on Betweenness. Sociometry, 40(1), 35-41. DOI: https://doi.org/10.2307/3033543

Guo S., Wu R., Tong Q., Zeng G., Yang J ., Chen L., Zhu T., Lv W., Li D. (2018), Is city traffic damaged by torrential rain? Physica A: Statistical Mechanics and Its Applications, 503(August 2017), 1073-1080. DOI: https://doi.org/10.1016/j.physa.2018. 08.044

Hsu Y. L., Lee C. H., Kreng V. B. (2010), The application of Fuzzy Delphi Method and Fuzzy AHP in lubricant regenerative technology selection. Expert Systems with Applications, 37(1), 419-425. DOI: https://doi.org/10.1016/j.eswa.2009.05.068

Hussain E. (2018), Modeling the effects of rainfall on vehicular traffic. Journal of Modern Transportation, 26(2), 133-146. DOI: https://doi.org/10.1007/s40534018-0155-0

Jahanshahi A., Kamali M., Khalaj M., Khodaparast Z. (2019), Delphi-based prioritization of economic criteria for development of wave and tidal energy technologies. Energy, 167, 819-827. DOI: https://doi.org/10.1016/j.energy.2018.11.040

Jefferies C., Doménech I. A. (2015), Report on Stormwater Management. Retrieved from https://www.
iiama.upv.es/iiama/src/elementos/Proyectos/e2storme d/D.3B.o1 Report on stormwater management.pdf

J ung S., Qin X., Noyce D. A. (2010), Rainfall effect on single-vehicle crash severities using polychotomous response models. Accident Analysis and Prevention, 42(1), 213-224. DOI: https://doi.org/10.1016/j.aap. 2009.07.020

Kamali M., Alesheikh A. A., Alavi Borazjani S. A., Jahanshahi A., Khodaparast Z., Khalaj M. (2017), Delphi-AHP and weighted index Overlay-GIS approaches for industrial site selection case study: Large extractive industrial units in Iran. Journal of Settlements and Spatial Planning, 8(2). DOI: https://doi.org/10.24193/JSSP.2017.2.03

Kamali, M. (2020), Guest editorial: an opinion on multi-criteria decision-making analysis for sustainability-based spatial planning practices. Time to improve? Journal of Settlements and Spatial Planning, In press, 1-3. DOI: https://doi.org/https://doi.org/ 10.24193/JSSPSI.2020.6.01 K

Kamali M., Alesheikh A. A., Khodaparast Z., Hosseinniakani S. M. S., Alavi Borazjani S. A. (2015), Application of Delphi-AHP and Fuzzy-GIS approaches for site selection of large extractive industrial units in Iran. Journal of Settlements and Spatial Planning, 6, 1-7. DOI: https://doi.org/ 10.24193/JSSP.2017.2.03

Kleinberg, J. O. N. (2003), Bursty and Hierarchical Structure in Streams. Proceedings of the 8th ACM SIGKDD International Conference on Knowledge Discovery and Data Mining, 373-397. DOI: https://doi.org/https://doi.org/10.1023/A:102494062 9314

Lee J ., Chae J., Yoon T., Yang H. (2018), Traffic accident severity analysis with rain-related factors using structural equation modeling - A case study of Seoul City. Accident Analysis and Prevention, 112(December 2017), 1-10. DOI: https://doi.org/10.1016/j.aap.2017. 12.013

Leimu R., Koricheva J. (2005), What determines the citation frequency of ecological papers? Trends in Ecology and Evolution, 20(1), 28-32. DOI: https://doi.org/10.1016/j.tree.2004.10.010

Lindner N. M., Hawkins C. B., J oy-gaba J ., Tenney E. R. (2010), Cumulative and career-stage impact of social-personality psychology programs and their members. Personality and Social Psychology Bulletin, (36), 1283-1300. DOI: 10.1177/014616721037 8111

Mingers J., Leydesdorff L. (2015), A review of theory and practice in scientometrics. European Journal of Operational Research, 246, 1-19. DOI: https://doi.org/10.1016/j.ejor.2015.04.002

Mitsakis E., Stamos I., Diakakis M., Salanova Grau J . M. (2014), Impacts of high-intensity storms on urban transportation: applying traffic flow control methodologies for quantifying the effects. International Journal of Environmental Science and Technology, 
11(8), 2145-2154. DOI: https://doi.org/10.1007/ s13762-014-0573-4

Napier F., J efferies C., Heal K. V., Fogg P., Arcy B. J. D., Clarke R. (2009), Evidence of traffic-related pollutant control in soil-based Sustainable Urban Drainage Systems (SUDS). Water Science and Technology, 6o(1), 221-230. DOI: https://doi.org/ 10.2166/wst.2009.326

Nielsen T. (1996), Traffic contribution of polycyclic aromatic hydrocarbons in the center of a large city. Atmospheric Environment, 30(20), 3481-3490. DOI: https://doi.org/10.1016/1352-2310(96)ooo96-9

Nzouonta J., Rajgure N., Wang G., Borcea C. (2009), VANET routing on city roads using real-time vehicular traffic information. IEEE Transactions on Vehicular Technology, 58(7), 3609-3626. DOI: https://doi.org/10.1109/TVT.2009.2014455

Olawumi T. O., Chan D. W. M. (2018), A scientometric review of global research on sustainability and sustainable development. Journal of Cleaner Production, 183, 231-250. DOI: https://doi.org/ 10.1016/j.jclepro.2018.02.162

Sunil Kumar R., Balakrishnan K., Jathavedan M. (2014), Betweenness Centrality in Some Classes of Graphs. arXiv:1403.4701 [math.CO].

Hounsell N. B., Shrestha B. P., Piao J., Mcdonald M. (2009), Review of urban traffic management and the impacts of new vehicle technologies. IET Intell. Transp. Syst., Vol. 3, 419-428. DOI: https://doi.org/10.1049/iet-its.2009.0046

Stathopoulos A., Karlaftis M. G. (2003), A multivariate state space approach for urban traffic flow modeling and prediction. Transportation Research Part C: Emerging Technologies, 11(2), 121-135. https:// doi.org/10.1016/So968-09oX(03)00004-4
Theofilatos A. (2017), Incorporating real-time traffic and weather data to explore road accident likelihood and severity in urban arterials. Journal of Safety Research, 61, 9-21. DOI: https://doi.org/10.1016/ j.jsr.2017.02.003

United States Environmental Protection Agency (2004), Bibliometrics Analysis for TSE Grant Publications.

Xu F., He Z., Sha Z., Zhuang L., Sun W. (2013), Assessing the Impact of Rainfall on Traffic Operation of Urban Road Network. Procedia - Social and Behavioral Sciences, 96(Cictp), 82-89. DOI: https://doi.org/ 10.1016/j.sbspro.2013.08.012

Yin H., Wong S. C., Xu J., Wong C. K. (2002), Urban traffic flow prediction using a fuzzy-neural approach. Transportation Research Part C: Emerging Technologies, 10(2), 85-98. https://doi.org/10.1016/ So968-090X(01)00004-3

Youn S., Chung E., Gu W., Hyun J. (2012), Resources, Conservation and Recycling Probabilistic estimation of the storage capacity of a rainwater harvesting system considering climate change. "Resources, Conservation \& Recycling," 65, 136-144. DOI: https://doi.org/10.1016/j.resconrec.2012.05.005

Zandi S., Nemati B., Jahanianfard D., Davarazar M., Sheikhnejad Y., Mostafaie A., Kamali M., Aminabhavi T. M. (2019), Industrial biowastes treatment using membrane bioreactors (MBRs) -a scientometric study. Journal of Environmental Management, 247, 462-473. DOI: https://doi.org/10.1016/j.jenvman.2019.06.066

Zhao Y., Shang J., Chen C. (2008), Simulation and evaluation on the eco-industrial system of Changchun economic and technological development zone , China. Environ Monit Assess, 139, 339-349. DPI: https://doi.org/10.1007/s10661-007-9840-x 